\title{
Microwave Heating as an Alternative Quarantine Method for Disinfestation of Stored Food Grains
}

\author{
Ipsita Das, ${ }^{1}$ Girish Kumar, ${ }^{1}$ and Narendra G. Shah ${ }^{2}$ \\ ${ }^{1}$ Department of Electrical Engineering, Indian Institute of Technology, Bombay, Powai, Mumbai 400076, India \\ ${ }^{2}$ Centre for Technology Alternatives for Rural Areas, Indian Institute of Technology, Bombay, Powai, Mumbai 400076, India
}

Correspondence should be addressed to Ipsita Das; ipsitdas@gmail.com

Received 17 December 2012; Accepted 28 February 2013

Academic Editor: Mitsuru Yoshida

Copyright (C) 2013 Ipsita Das et al. This is an open access article distributed under the Creative Commons Attribution License, which permits unrestricted use, distribution, and reproduction in any medium, provided the original work is properly cited.

Insects and pests constitute a major threat to food supplies all over the world. Some estimates put the loss of food grains because of infestation to about $40 \%$ of the world production. Contemporary disinfestation methods are chemical fumigation, ionizing radiation, controlled atmosphere, conventional hot air treatment, and dielectric heating, that is, radio frequency and microwave energy, and so forth. Though chemical fumigation is being used extensively in stored food grains, regulatory issues, insect resistance, and environmental concerns demand technically effective and environmentally sound quarantine methods. Recent studies have indicated that microwave treatment is a potential means of replacing other techniques because of selective heating, pollution free environment, equivalent or better quality retention, energy minimization, and so forth. The current paper reviews the recent advances in Microwave (MW) disinfestation of stored food products and its principle and experimental results from previous studies in order to establish the usefulness of this technology.

\section{Importance of Disinfestation}

Agricultural commodities produced on the fields have to undergo a series of operations such as harvesting, threshing, winnowing, bagging, transportation, storage, and processing before they reach the consumer, and there are appreciable losses in crop output at all these stages. Various estimates have been made to assess the postharvest food grain losses. The losses are caused either by environmental factors such as temperature, moisture, and type of storage structure or by biological agents, namely, insects, rodents, birds, and fungi. The major losses during production, storage and marketing of food grain are being attributed to infestation by insect pests, microbiological contamination, and physiological changes. Insect infestations can occur just prior to harvest or during storage or in-transit in a variety of carriers. The occurrence and numbers of stored grain insect pests are directly related to geographical and climatic conditions [1]. Almost all species have remarkably high rates of multiplication and, within one season, may destroy $10-15 \%$ of the grain and contaminate the rest with undesirable odors and flavors. Insect pests also play a pivotal role in transportation of storage fungi [2]. Therefore, preventing economic losses caused by stored-product insects is important from the field to the consumer's table [3]. The losses during storage are classified as quantity losses and quality losses. Quantity losses occur when the grain is consumed by insects, rodents, mites, birds and microorganisms. Quality losses are reflected as reduced economic value of the crop. The stored-grain insects affect not only the quantity of grain but also the quality of grain. Infestation causes decreased nutritional value, reduced seed germination, and lower economic value and also causes changes in chemical compositions such as increase in moisture, free fatty acid levels, nonprotein nitrogen content, and decrease in $\mathrm{pH}$ and protein contents in food grain [4]. They reduce the product quality directly by damage through feeding and indirectly by producing webbing and frass [5]. Also the grain quality has been found to decrease with time with increasing levels of infestation [6]. It is estimated that more than 20,000 species of field and storage pests destroy approximately one-third of the world's food production, valued annually at more than 100 billion dollar [7]. The quantitative and qualitative damage to stored grains 
and grain product from the insect pests may amount to 20$30 \%$ in the tropical zone and $5-10 \%$ in the temperate zone [8]. Food grain production in India has reached 250 million tons in the year 2010-2011, in which nearly 20-25\% food grains are damaged by stored grain insect pests [7]. With population growth and the amount of cultivatable land shrinking, grain losses will continue to be a problem in the developing countries. Control of stored-product pests is one of the major tasks because the damage inflicted to foodstuff is irreversible. Also with progressive increase in the quantity of food grains and necessity for longer storage periods, these losses will escalate unless disinfestation measures are improved. International organizations such as FDA [9] and FGIS [10] have set tolerances and grade standards regulating the number of insects and insect fragments above specified tolerances to make the product illegal for human consumption. In developed countries even the mere presence of a few insects in a bulk, at densities of considerably less than one insect per kg grain, can cause a serious loss in its market value. In some developed countries grain can be downgraded or rejected completely if even a single live insect is found [11]. The efficient control and removal of stored grain pests from food commodities have long been the goal of entomologists throughout the world. Various methods of insect control have been practiced to save the grain. In recent years, technology has made marked progress in the study of disinfestation of stored-grain insects and of finding improved ways to control them especially to detect latent forms of infestation. The implementation of an insect-disinfestation method requires detailed analysis of all the elements of an infestation problem: the insects, their age, species, and distribution and their survival and developmental rates under different environmental conditions [12]. Conventional chemicals, grain protectants, and fumigants are extensively used around the world to control insect pests in stored commodities because of low cost, fast processing, and easy application. Greater regulation and restriction of methyl bromide use will likely increase the cost of the fumigant, as well as reduce its availability [13]. With the concerns about health hazards of chemical pesticides and their resulting environmental pollution, there is interest in developing alternative, nonchemical process protocol to control insect pests while retaining acceptable product quality. These include conventional hot air or water heating, controlled atmosphere, and dielectric heating (radio frequency $(\mathrm{RF})$ and microwave $(\mathrm{MW})$ ). Currently, the use of chemical fumigation remains widespread and the efficient use of RF and MW methods for disinfestation is still in research stage. The current paper reviews the various disinfestation methods of stored food grains with special emphasis on recent advances in microwave disinfestation of stored food grains. The principle of microwave disinfestation, experimental results of quality characteristics of microwave-treated grains, and the challenges of microwave disinfestation have also been described.

\section{Various Methods of Insect Control}

The control of stored-product insects is very important if the quality of foodstuff is to be maintained. The goal of the control measure is to render the habitat unsuitable for the growth and reproduction of stored-product insects. The five major potential quarantine treatment methods used for disinfestation of several insect pests for both the domestic and international markets are chemical fumigation, ionizing radiation, controlled atmosphere, conventional hot air/water heating, and dielectric heating using radio frequency (RF) and microwave (MW) energy which have been described in this paper.

2.1. Chemical Method. Since the 1950 s, chemical insecticides have been used extensively in grain storage facilities to control stored-product insect pests due to low cost, fast speed in processing, and ease of use. Most postharvest pest management programs, therefore, rely heavily on fumigants. Currently, over 2.5 million tons of chemicals, worth over 30 billion US dollars, are applied to crops in the world [14]. The chemicals used to control insects in the bulk stored-grains are composed of two classes, namely, contact insecticides and fumigants. Contact insecticides, such as malathion, chlorpyrifos-methyl, or deltamethrin, are sprayed directly on grain or structures which provide protection from infestation for several months [15]. Fumigants are gaseous insecticides applied to control insects in grains that are inaccessible by contact insecticide. Some of the commonly used fumigants are methyl bromide $(\mathrm{MeBr})$ and phosphine which rapidly kill all life stages of stored-product insects in food product [16]. Methyl bromide is now under the threat of withdrawal because it apparently depletes the Earth's ozone layer [17]. It has already been established that the use of $\mathrm{MeBr}$ has led to serious environmental damage and hazards to people's health. For these reasons, the Montreal Protocol constituted by the United Nations Environment Programme agreed on a phasing out of methyl bromide in the developed countries by 2005 and in the developing countries by 2015 [18]. Phosphine has been used as a replacement of methyl bromide for a long time [19]. Conventional use of phosphine has failed frequently to control insects [20]. Another limiting factor is that insects develop resistance to some particular chemical fumigants. Some of the contact insecticides have become ineffective because of wide-spread resistance in insect populations. A worldwide survey of stored-product insects revealed that $87 \%$ of 505 strains of the red flour beetle, Tribolium castaneum, collected from 78 countries were resistant to malathion [15]. Resistance to malathion is widespread in Canada, USA, and Australia [21] while resistance to phosphine is great in Australia and India, which may cause control failures [22]. The other major problem associated with the chemical methods is that, even if they are applied with care and in limited quantity, there is a possibility that these chemicals may remain in the food grains and have adverse effects on humans. Fumigation often only kills live larvae or adult insects but does not sterilize the eggs which are still alive in the grain kernels [23]. The consumption of organic products is also increasing each year. There is, therefore, interest in developing an alternative, nonchemical process method to control insect pests in food grains so as to minimize the environmental hazards associated with chemical insecticides while retaining acceptable product quality. 
2.2. Ionizing Radiation. It is a process where infested food products are being exposed to ionizing radiation so as to sterilize, kill, or prevent emergence of insect pests by damaging their DNA. Three types of ionizing radiation used on foods are gamma rays from radioactive cobalt60 and cesium-137, high energy electrons, and X-rays [24]. Irradiation with high energy electrons is usually safer and easier to work with because it can be turned on and off while an isotope is always radiating and humans must be shielded from it [25]. The ability of gamma rays to deeply penetrate pallet loads of food makes it one of the most commonly used in postharvest pest control. Sterilization of many species of insects can be accomplished at lower doses. Rusty grain beetles are sterilized at only $0.6 \mathrm{kGy}$ but sawtoothed grain beetles and red flour beetles require a $2.0 \mathrm{kGy}$ dose [26]. The grain mite, however, requires a much higher dose of $4.5 \mathrm{kGy}$. Though irradiation doses of 3-5 kGy were reported to be effective in controlling insects, they cause damage to product quality [26]. According to Hasan and Khan [27], high dosage of ionizing radiation has a risk of vitamin loss from the food product. The major drawback is substantial initial investment to establish the facility. In order to be economically feasible, the facility must remain in continuous operation. However, the seasonal nature of food produce prevents efficient use of facilities. Besides, this method has not received wide recognition because of high power consumption, large weight, and overall sizes of the installation. Consumers also have concerns over the disposal of radioactive wastes, the safety of the irradiation technology, and its effect on food [28]. Irradiation treatments often lead to live insects found by inspectors or consumers in the treated product because the applied doses do not immediately kill treated insects $[29,30]$. Grains will continue to appear to be infested and a grain buyer cannot be certain that the insects are sterilized. Following irradiation with gamma rays at $0.5 \mathrm{kGy}$, complete insect mortality occurs in 14 days for rusty grain beetles, 28 days for red flour beetles, 70 days for saw-toothed grain beetles, and 200 days for grain mites. To date, irradiation is not accepted by the organic industry. Also approvals for irradiation of some selected food products (e.g., almond) have not been accepted by many countries, such as EU, Japan, and Taiwan [31].

2.3. Controlled Atmosphere Storage. Controlled atmosphere, a disinfestation technology wherein the normal composition of atmospheric air, that is, $21 \% \mathrm{O}_{2}, 0.03 \% \mathrm{CO}_{2}$, and $78 \%$ nitrogen, is altered appropriately for disinfestation process [26]. An atmosphere containing more than $35 \% \mathrm{CO}_{2}$ known as carbon dioxide atmosphere and the atmosphere containing less than $1 \%$ oxygen, that is, low-oxygen atmosphere are lethal to insects. Controlled atmospheres are mainly based on the establishment of a low-oxygen environment which kills pests. The oxygen levels vary between $0 \%$ and $2 \%$. It can be applied in airtight environments ranging from $1 \mathrm{M}^{3}$ to $1000 \mathrm{M}^{3}$ depending upon food commodity. Insects in all stages are eliminated because of the lack of oxygen which causes the insect to dry out and suffocate. This controlled atmosphere (CA) storage has been shown to be promising in creating lethal conditions for insects and fungi in stored food commodities. Annis and Morton [36] studied the effect of $15 \%$ to $100 \% \mathrm{CO}_{2}$ on developmental stages of insects in wheat at $25^{\circ} \mathrm{C}$ and $60 \% \mathrm{RH}$. They found that pupae were the most tolerant stages for all $\mathrm{CO}_{2}$ concentrations and eggs were the only stages with $100 \%$ mortality at $20 \% \mathrm{CO}_{2}$ for less than 30 days. Gunasekaran and Rajendran [37] also found that the pupae stages were the most tolerant stages when exposed to different concentrations of $\mathrm{CO}_{2}$. Controlled atmospheres are always being seen as average alternative such as longer treatment time, usability and availability, and being not suitable for dealing with high level of infestation.

2.4. Conventional Heat Treatment. Compared to the use of chemical methods, heat disinfestation has the potential for high market acceptance because of being residue-free. Most research focused on using hot air $\left(80^{\circ} \mathrm{C}\right.$ to $\left.100^{\circ} \mathrm{C}\right)$ for disinfestation of food grains and showed satisfactory results. Thermal treatment methods using hot air/hot water alone or in combination with cold or controlled-atmosphere (CA) storage conditions have been investigated extensively for disinfestation of number of stored commodities [28, 3855]. The hot air used to increase the temperature of the food product lies above the thermal limits of survival of the pest/insect. Heat disinfestation treatments are relatively easy to apply, leave no chemical residues, and may offer some fungicidal activity. There are a number of factors that affect the mortality of insects when exposed to hot air such as duration of exposure, temperature, species, and stage. Ideal temperatures for growth, reproduction, and movement for most stored product insects are between $25^{\circ} \mathrm{C}$ and $35^{\circ} \mathrm{C}$ [56]. Many insect larvae can bore into the center of fruits, nuts, seeds, or kernels, so the center of the commodity must be heated to lethal temperatures. Reported heating times for fruit center to reach the desired maximum temperatures range from $23 \mathrm{~min}$ for cherries to $6 \mathrm{~h}$ for apples $[48,49]$. Conventional heating consists of heat transfer from the heating medium to the fruit surface and then conductive heat transfer from the surface to the center. A common difficulty with hot air or water heating methods is the slow rate of heat transfer resulting in long treatment time [57]. Prolonged heating is proved to be detrimental to the quality of final products such as peel browning, pitting, poor color development, and abnormal softening and may not be practical in industrial applications ([58], cited by [59]). There were reports of damage to grapefruits and mangos when exposed to forced air at $46^{\circ} \mathrm{C}$ for $3.75 \mathrm{~h}$ and $45^{\circ} \mathrm{C}$ for $1.8 \mathrm{~h}$, respectively $([60,61]$ cited by [48]). Flavor and appearance of air-heated grapefruits at $46^{\circ} \mathrm{C}$ for $3 \mathrm{~h}$ were inferior to those of unexposed fruits [62]. Surface browning in avocados was observed when heated with hot air at $43^{\circ} \mathrm{C}$ for $3.5 \mathrm{~h} \mathrm{[63]} \mathrm{and}$ in apples when exposed to hot water treatment at $46^{\circ} \mathrm{C}$ for $45 \mathrm{~min}$ [64]. A long exposure time requirement also causes alterations to flavor compounds [65]. The low heating rates also may increase the thermotolerance of the few insects [6668] which was caused by the induction of heat shock proteins in insects during sublethal thermal conditions [69]. It is also important to determine the time-temperature combinations 
that result in $100 \%$ mortality for each insect over relatively large range of temperature. Sometimes temperature and time combinations required to kill the target insects may exceed those that reduce the crop nutrients, germination, or shelf life [70]. The disadvantages associated with conventional heat treatment method stimulated further studies on the possible use of dielectric heating for controlling stored-grain insects.

2.5. Dielectric Heating. Dielectric heating which covers both radio frequency (RF) and microwave (MW) has been investigated for insect control in foods [71]. Radio frequency (RF) heating is akin to microwave heating but utilizes another part of the electromagnetic spectrum. The frequency used for $\mathrm{MW}$ is $2450 \mathrm{MHz}$ or $915 \mathrm{MHz}$ while for RF the frequency is of 13,27 , or $40 \mathrm{MHz}$ [48]. The effects of RF and MW energy are generally believed to be mainly thermal in nature [72]. Most agricultural products that considered dielectric material can store electric energy and convert electric energy into heat [49]. As the wavelength of RF heating frequencies is 22 to 360 times as more than that of the microwave frequencies, this allows RF energy to penetrate dielectric materials more deeply than microwaves. Many studies have explored the use of RF heating for control of insects in agricultural commodities [31, 47, 49, 73-82]. Researchers have reported the acceptable product quality after treating nuts and rice with RF energy to control insect infestation [48, 76-78, 83-85]. Recently, Wang et al. [81] studied postharvest disinfestation treatments for chickpeas and lentils using RF energy and also reported acceptable product quality. But the radio frequency heating is particularly useful when applied to institutional-sized packaged food products because of its deep penetration $[86,87]$.

Thermal treatment methods involving microwave radiation have extensively been investigated by several researchers as an alternative method of killing insects. Microwave quarantine method seems to have a great potential as an alternative method of killing insects in stored grain because of several advantages such as the control of all developmental stages of storage pests, having no chemical residues on the food product, having minimal impact on the environment, and providing rapid heating [28, 88-90]. Insects are unlikely to develop resistance to this treatment [91]. This electromagnetic energy (MW and RF) interacts directly with the product's interior to quickly raise the center temperature [47-49]. Microwave radiation not only kills insects by the dielectric heat induced within them but also affects the reproduction of survivors [92]. Microwave radiation, with good penetrability, can kill pests existing inside or outside grain kernels [93]. This paper brings the research initiatives especially on microwave (MW) heating for their potential use for disinfestation of stored food grains.

2.5.1. Microwave Heating. Microwaves are electromagnetic waves with frequencies ranging from about $300 \mathrm{MHz}$ to $300 \mathrm{GHz}$ and corresponding wavelengths from 1 to $0.001 \mathrm{~m}$ [94]. In electromagnetic spectrum, microwaves lie between radio frequencies and infrared radiation. Microwave heating is based on the transformation of alternating electromagnetic field energy into thermal energy by affecting polar molecules of a material. Many molecules in food (such as water and fat) are electric dipoles, meaning that they have a positive charge at one end and a negative charge at the other, and therefore they rotate as they try to align themselves with the alternating electric field induced by the microwave beam. The rapid movement of the bipolar molecules creates friction and results in heat dissipation in the material exposed to the microwave radiation. Microwave heating is most efficient on liquid water and much less on fats and sugars (which have less molecular dipole moment) [95]. The most important characteristic of microwave heating is volumetric heating which is different from conventional heating. The electromagnetic energy directly interacts with commodities to raise the interior temperature and significantly reduce treatment times as compared to conventional hot-water immersion and heated air methods. Conventional heating occurs by convection or conduction where heat must diffuse from the surface of the material. Volumetric heating means that materials can absorb microwave energy directly and internally and convert it into heat. The power generated in a material is proportional to the frequency of the source, the dielectric loss of the material, and the square of the field strength within it. The conversion of microwave energy to heat is expressed by the following equation [96]:

$$
p=2 \pi E^{2} f^{\prime \prime} \varepsilon_{0} V
$$

where $p$ : power, $\mathrm{W}, E$ : the electric field strength, $\mathrm{V} / \mathrm{m}, f$ : the frequency, $\mathrm{Hz}, \varepsilon_{0}$ : the permittivity of free space, $\mathrm{F} / \mathrm{m}, \varepsilon^{\prime \prime}$ : the dielectric loss factor, and $V$ : volume of the material, $\mathrm{m}^{3}$.

Dielectric properties of food depend on composition, temperature, bulk density, and microwave frequency. Since the influence of a dielectric depends on the amount of mass interacting with the electromagnetic fields, the mass per unit volume, or density, will also have an effect on the dielectric properties. This is especially notable with particulate dielectrics such as food grains. For granular and particulate materials, both the dielectric constant and loss factor tend to increase linearly with increasing bulk density of the materials especially in lower moisture materials such as cereal grains [97].

2.5.2. Microwave Disinfestation. The use of microwaves for disinfestation is based on the dielectric heating effect produced in grain, which is a relatively poor conductor of electricity. An attractive feature of the insect control using the microwave energy is that the insects are heated at a faster rate than the product they infest because of high moisture content of insects. So, it is possible to heat the insects to a lethal temperature because of their high moisture content while leaving the drier foodstuff unaffected or slightly warm [12]. Raising the temperature of infested materials by any means can be used to control insects if the infested product can tolerate the temperature levels that are necessary to kill the insects. There has been a lot of research on microwave disinfestation of cereals especially wheat [33, 98-104] and of some other food materials such as nuts [28], corn [105], pulses $[106,107]$, and cherries [89]. Exposure to microwave energy 
TABLE 1: Dielectric properties of insects at $20-25^{\circ} \mathrm{C}$ ([32] cited by [33]).

\begin{tabular}{|c|c|c|c|c|c|c|c|c|}
\hline \multirow{3}{*}{ Adult insect species } & \multicolumn{8}{|c|}{ Frequency $(\mathrm{GHz})$} \\
\hline & \multicolumn{2}{|c|}{0.2} & \multicolumn{2}{|c|}{2.4} & \multicolumn{2}{|c|}{9.4} & \multicolumn{2}{|c|}{20} \\
\hline & $\varepsilon^{\prime}$ & $\varepsilon^{\prime \prime}$ & $\varepsilon^{\prime}$ & $\varepsilon^{\prime \prime}$ & $\varepsilon^{\prime}$ & $\varepsilon^{\prime \prime}$ & $\varepsilon^{\prime}$ & $\varepsilon^{\prime \prime}$ \\
\hline S. oryzae & 28 & 12 & 17 & 3 & 17 & 3 & - & - \\
\hline L. decemlineata & 53 & 81 & 38 & 12 & 30 & 16 & 19 & 17 \\
\hline S. oryzae & 42 & 28 & 32 & 9 & 25 & 12 & 18 & 13 \\
\hline S. oryzae & 55 & 48 & 42 & 13 & 31 & 16 & 23 & 16 \\
\hline T. castaneum & 61 & 56 & 47 & 15 & 34 & 19 & 25 & 19 \\
\hline O. surinamensis & 70 & 68 & 53 & 17 & 40 & 21 & 28 & 22 \\
\hline R. dominica & 63 & 55 & 43 & 15 & 34 & 19 & 25 & 18 \\
\hline
\end{tabular}

$\varepsilon^{\prime}$ : dielectric constant, $\varepsilon^{\prime \prime}$ : dielectric loss.

could cause physical injuries and reduced reproduction rates in surviving insects [75].

Feasibility of microwave disinfestation of insect pests has been explored by Andreuccetti et al. [74] for woodworms and by Halverson et al. [108] for wheat, maize, and flour weevils (cited by [89]). Nelson [75] reviewed the susceptibility of various stored grain insect species to radio frequency and microwave treatments. The use of microwave energy to control insects was initiated by Webber et al. [109] and the literature prior to 1980 has been reviewed by Tilton and Vardell [98]. Researchers have reported that microwave treatment is an attractive quarantine treatment. The major advantage of microwave heating is that it interacts directly with food grains and significantly reduce the amount of time required for food grain to reach the lethal temperature for insects as compared with conventional heating methods. Based on microwave heating theory and dissipated power calculations in (1), the absorption of microwave energy is proportional to the dielectric constant and dielectric loss factor of the materials. The dielectric properties of the materials depend on the frequency of the applied electric field and the temperature of the material [110]. If the material is hygroscopic, dielectric properties also depend on the amount of water in the material [111].

The first reported measurements of insect dielectric properties were for rice weevil and flour beetle at $40 \mathrm{MHz}$ frequency. The dielectric constants were 6.6 and 7.8 for rice weevil and flour beetle, respectively, and loss factor was 2.2 for both species [112-114]. Nelson [110] presented data that confirms the dielectric loss factor of the insects was found to be much higher than that of stored-grain insects. The insect permittivity data at $25^{\circ} \mathrm{C}$ for $2.47 \mathrm{GHz}$ frequency reported by Nelson et al. [32] are shown in Table 1. Alfaifi et al. [115] have reported that the loss factor of insect pests, such as Indian meal moth (Plodia interpunctella) and navel orangeworm (Amyelois transitella), is 26 to 36 times greater than that of dried fruits. Wang et al. [28, 48, 49] have indicated preferential heating of insects when walnut kernels and codling moth were subjected to radio frequency $(27 \mathrm{MHz})$ and microwave frequency $(2450 \mathrm{MHz})$ heating. Similar finding was observed by Ikediala et al. [116] and Raskovan et al. [117] for insect infested grain when subjected to radio frequency heating.
TABLE 2: Dielectric properties of selected food products at $20^{\circ} \mathrm{C}$.

\begin{tabular}{lcccc}
\hline \multirow{2}{*}{ Food product } & \multicolumn{2}{c}{ Dielectric constant } & \multicolumn{2}{c}{ Dielectric loss } \\
& $915 \mathrm{MHz}$ & $2450 \mathrm{MHz}$ & $915 \mathrm{MHz}$ & $2450 \mathrm{MHz}$ \\
\hline Apple & 57 & 54 & 8 & 10 \\
Almond & 2.1 & - & 2.6 & - \\
Avocado & 47 & 45 & 16 & 12 \\
Banana & 64 & 60 & 19 & 18 \\
Carrot & 59 & 56 & 18 & 15 \\
Cucumber & 71 & 69 & 11 & 12 \\
Dates & 12 & - & 5.7 & - \\
Grape & 69 & 65 & 15 & 17 \\
Grapefruit & 75 & 73 & 14 & 15 \\
Lemon & 73 & 71 & 15 & 14 \\
Lime & 72 & 70 & 18 & 15 \\
Mango & 64 & 61 & 12 & 14 \\
Onion & 61 & 64 & 12 & 14 \\
Orange & 73 & 69 & 14 & 16 \\
Papaya & 69 & 67 & 10 & 14 \\
Peach & 70 & 67 & 12 & 14 \\
Pear & 67 & 64 & 11 & 13 \\
Potato & 62 & 57 & 22 & 17 \\
Radish & 68 & 67 & 20 & 15 \\
Strawberry & 73 & 71 & 14 & 14 \\
Walnut & 3.2 & - & 6.4 & - \\
\hline Sarce: & & & &
\end{tabular}

Source: see [34].

They have reported that the dielectric constant and dielectric loss factor for granary weevil were greater than those of host grain in frequency band from 2 to $150 \mathrm{MHz}$. The reason attributed is that the higher the water content, the higher the values of dielectric properties of a material [118] which consist of dielectric constant $\left(\varepsilon^{\prime}\right)$ and dielectric loss factor $\left(\varepsilon^{\prime \prime}\right)$ described by the complex relative permittivity $\varepsilon^{*}[115,119]$ :

$$
\varepsilon^{*}=\varepsilon^{\prime}-j \varepsilon^{\prime \prime},
$$

where $j=(-1)^{0.5}, \varepsilon^{\prime}=$ real component, a measure of the ability of the material to store electromagnetic energy, and $\varepsilon^{\prime \prime}=$ Imaginary component, a measure of the ability to dissipate electrical energy into heat.

Table 2 shows the dielectric permittivity of food when subjected to microwave heating. Hallman and Sharp [120] also summarized research on the application of radio frequency and microwave heat (electromagnetic energy) treatments to kill different pests on many postharvest food crops. Power level and exposure time of microwave have been identified as two important parameters to provide $100 \%$ insect mortality [101]. Microwave energies have been investigated for a number of food products other than cereal grains such as pulses, nuts, cherries, and dates. Recently, the effect of the microwave-heating method has been studied on disinfestations of the stored green gram seed [107]. The power level and exposure time were optimized based on insect mortality, color, and antinutrient factor with the value of power and exposure time of $800 \mathrm{~W}$ and $80 \mathrm{~s}$, respectively. Singh et al. [106] have also studied the disinfestation of pulse beetle (adult 
stage) in chickpea, pigeon pea, and green gram as a function of exposure time and power level by exposing it continuously to microwave radiation $(2450 \mathrm{MHz})$. The mortality of insect was found to increase with increase in microwave exposure time and power level or both. Though seed viability and germination of all these pulses were found to be affected, the cooking and milling characteristics were not affected by microwave exposure time and power level. Campana et al. [121] and Bhaskara Reddy et al. [122] that though eradication of the insects increased with the increase in microwave energy, but the seed viability, germination capacity, and seedling vigour decreased by exposure to microwave energy. Vadivambal et al. [104] and Vadivambal [33] had studied the mortality of different life stages of three common stored-grain insects, namely, Tribolium castaneum (Herbst), Cryptolestes ferrugineus (Stephens) and Sitophilus granarius (L.) in wheat, barley, and rye, respectively, using industrial microwave dryer operating at $2.45 \mathrm{GHz}$. Grain samples of $50 \mathrm{~g}$ at $14 \%, 16 \%$, and $18 \%$ moisture content (wet basis) were exposed to four different power levels of 200,300, 400, and $500 \mathrm{~W}$ for two exposure times of 28 and $56 \mathrm{~s}$. Complete (100\%) mortality was achieved for adults of all three insect species at $500 \mathrm{~W}$ for an exposure time of $28 \mathrm{~s}$. The average temperature of wheat, barley, and rye at $500 \mathrm{~W}$ and $28 \mathrm{~s}$ was around $80^{\circ} \mathrm{C}, 71^{\circ} \mathrm{C}$ and $82^{\circ} \mathrm{C}$, respectively. In all the cases, eggs were found to be most susceptible followed by larvae, and the least susceptible were the pupae and adults. Halverson et al. [103] had also reported that egg and young larva of all the three species were more susceptible than the pupa when microwave energy at $28 \mathrm{GHz}$ frequency. The species tested were $S$. granarius, T. castaneum and $R$. dominica. Germination of seeds was lowered with an increase in power level or exposure time or both but there was no significant difference found in the quality characteristics of microwave-treated and control wheat, barley and rye except for a decrease in the flour yield. There were also reports by several researchers that no significant difference in the quality of grain protein, flour protein, flour yield, and loaf volume of sample was found when treated with microwave energy at which $100 \%$ mortality was obtained.

Kaasova et al. [123] studied the chemical and biochemical changes during microwave treatment of wheat and reported that an improvement in the baking quality was found at higher energy doses and higher product temperatures. The decrease in germination capacity/seedling viability was related to the final temperature and the initial moisture content of the grains. Hamid and Boulanger [124] had found that the bread making quality of wheat was affected with increase in treatment temperature when exposed to power of $1.2 \mathrm{~kW}$. They reported that $70 \%$ and $100 \%$ mortality were obtained when the wheat temperature was $55^{\circ} \mathrm{C}$ and $65^{\circ} \mathrm{C}$, respectively, while, Locatelli and Traversa [125] have reported that temperature of grain has to reach $80^{\circ} \mathrm{C}$ for achieving complete mortality of insects infected using microwave. In fact, most infesting biological agents do not survive over a certain temperature called lethal temperature, generally between $55^{\circ} \mathrm{C}$ and $60^{\circ} \mathrm{C}$, which can be rapidly reached through microwave irradiation [40]. There are three temperature zones for all insects: optimum, the zone at which highest rate of development can be achieved; suboptimum,
TABLE 3: Response of stored-product insects to temperature [35].

\begin{tabular}{|c|c|c|}
\hline Temperature $\left({ }^{\circ} \mathrm{C}\right)$ & Zone & Effect \\
\hline $50-60$ & \multirow{2}{*}{ Lethal } & Death in minutes \\
\hline 45 & & Death in hours \\
\hline 35 & \multirow{2}{*}{ Suboptimum } & Development stops \\
\hline $33-35$ & & Development slows \\
\hline $25-33$ & Optimum & Maximum rate of development \\
\hline $13-25$ & \multirow{2}{*}{ Suboptimum } & Development slows \\
\hline $13-20$ & & Development stops \\
\hline 5 & \multirow{3}{*}{ Lethal } & Death in days \\
\hline-10 to -5 & & Death in weeks to month \\
\hline-25 to -15 & & Death in minutes, insects freeze \\
\hline
\end{tabular}

a zone below or above optimum during which insects can complete their life cycle; and thirdly lethal zone, above or below suboptimum zones when insects get killed over period of time (Table 3). But the lethal temperatures to kill insects were found to vary considerably not only with species but also with the stage of development, temperature, and relative humidity. When developing effective treatment protocols, it is essential to determine which of the targeted insects is the most heat resistant, as well as the most heat resistant life stage for each species. To accomplish this, information is required on the minimum time-temperature combinations that result in $100 \%$ mortality for each insect over a relatively large range of temperature. The thermal death kinetics for fifth-instars of Indian meal moth, codling moth, and navel orange worm have been separately reported $[76,77,126-$ 129]. The authors of [130] recommended $15 \mathrm{~min}$ exposures to microwaves, which increased temperature to $60^{\circ} \mathrm{C}$ to kill all insects in confectionery walnuts without adversely affecting flavor.

Halverson et al. [103] conducted experiments to determine life stages of the insect that is most susceptible to microwave energy at $28 \mathrm{GHz}$ frequency. The life stages tested were egg, young larva, and pupa. Their results suggested that egg and young larva of all were always more susceptible than the pupa. Zouba et al. [131] had employed a researchscale microwave unit to investigate the mortality of insect in date and the thermal impact on the date quality. The heating characteristics of dates are highly influenced by initial moisture content. Date having various moisture contents gets heated up in a very heterogeneous manner and the energy of the microwaves seems to be preferentially absorbed by soft dates. Similar results were reported during insect control of walnuts using radio frequency treatments. The insect mortality is achieved in less than $90 \mathrm{~s}$ during microwave treatment without altering date quality.

\subsubsection{Challenges in Microwave Disinfestation. Although} microwaves have potential for disinfestation applications in the grain industry, they have not been used widely due to their adverse effects on various quality parameters. The major problems associated with microwave heating are the nonuniform temperature distribution and thereby incomplete kill of microbes [132-137]. Hot spots, produced on products 
due to the nonuniform heating pattern of microwaves, are one of the important factors for the quality degradation of products during microwave treatment. A hot spot can be defined as a local area of very high temperature that results from the temperature dependence of material properties. Although hot spots are desirable to increase insect mortality, detrimental effects on the medium are not. Manickavasagan et al. [138] had determined the germination percentage of microwave-treated wheat samples collected from hot-spot and normal heating zones. The wheat samples having four different moisture levels (12\%, 15\%, 18\%, and 21\% wb) were subjected to different microwave treatments $(100,200,300$, 400 , and 500 watt with exposure times of 28 and $56 \mathrm{~s}$ ) in continuous industrial microwave dryer $(2450 \mathrm{MHz})$. The germination percentage of the sample in the hot-spot region was significantly lower than that of the normal heating region for all moisture and power levels. Apart from germination, the other quality parameters were also found to get affected more in the hot-spot zone than the remaining bulk grain. Moreover, the generation of "hot spots" during industrial microwave heating has recently become of great concern to scientists involved in microwave research $[139,140]$. The other major drawback in microwave disinfestation is the poor penetrating power of microwaves. The microwave's intensity diminishes with increased penetration. It has been reported that microwave treatment of bulk grain is not feasible when the depth is greater than 4 inch ([92] cited by [33]). Due to the limited penetration of microwave energy into foodstuff mass, it seems likely that employment of microwave radiation alone could not be considered as a promising insect control measure under field condition. Disinfestations of stored products using microwaves energy coupled with other modes of treatment can be an alternative measure in killing insects effectively, but little work has been reported on combined application. The mechanisms involved in the lethal action of microwave radiation are already understood. Microwave radiation has effects on insects such as reduction of reproductive rate, losing body weight, and malformation [75]. However, application of microwaves radiation could be limited due to insufficient penetration depth. Songping et al., [140] reported that microwaves attenuate exponentially in penetration to foodstuffs.

Combined application of microwaves with hot-air treatment/cold storage/gamma radiation could be considered as a potential measure which can help reduce stored-product insects population. The combined impact of microwave radiation and cold storage on adults was evaluated by several researchers. Ayvaz and Karabörklü [141] had reported that there is a decrease in reproductive ability and number of living adults depending on the length of the cold storage period. In general, the reduction of temperature in the environment stresses the insect, thereby, making it more susceptible to other control measures $[48,89]$. The major advantage is that the cold storage can easily be coupled with microwave radiation for pest control measure. There was sufficient indication that longer microwaves energy exposure and cold storage duration could achieve better kill than shorter ones of similar power level. When the insects such as Tribolium castaneum H. and Sitophilus oryzae L. were exposed to $2450 \mathrm{MHz}$ at power level of $100 \mathrm{~W}$ for exposure time $10 \mathrm{~min}$, continuously and intermittently, the highest rate of mortality was achieved for intermittent exposure time of $10 \mathrm{~min}$ and $72 \mathrm{~h}$ of cold storage duration [142]. Valizadegan et al. [143] have also evaluated the impact of microwave radiation in conjunction with cold storage on adult insects (saw-toothed grain beetle and cigarette beetle) under laboratory conditions. The insects were exposed to $2450 \mathrm{MHZ}$ at five different power levels of 0, 100, 200, 300, and $400 \mathrm{~W}$ for five exposure times of $0,3,6,9$, and $12 \mathrm{~min}$. The complete control was achieved at $400 \mathrm{~W}$ power levels for exposure time of $12 \mathrm{~min}$ and $72 \mathrm{~h}$ cold storage period. Similar results, that is, high mortality rate, were also reported by Nasab et al. [5] when Indian meal moth eggs were exposed to power levels of 100,300 , and $500 \mathrm{~W}$ with $2,4,6,8$, and $10 \mathrm{~min}$ exposure duration along and then kept in cold storage conditions $\left(4 \pm 1^{\circ} \mathrm{C}\right)$ for 24 and $48 \mathrm{~h}$. Combinations of microwave radiation and cold storage were found to be compatible and synergistic which provide an effective and environmentally friendly disinfestation treatment technique.

Researchers have also tried the microwave heating along with gamma irradiation to control insects in stored cereals and cereals products. El-Naggar and Mikhaiel [144] evaluated the biochemical analyses on the samples of wheat grain and flour subjected to combined microwave and gamma irradiation treatment where high mortality was obtained. There were no detectable changes in the quality of protein, fat, fiber, carbohydrates, or ash. Amjad and Akbar Anjum [145] stated that when onion seeds (Allium cepa L.) were exposed to various doses of gamma radiation, that is, $0,20,40,80$, and $100 \mathrm{krad}$, there was no significant effect on seed viability except at the highest dose $(100 \mathrm{krad})$ which resulted in reduced viability. But several other researchers reported that microwaves are not suitable for the drying of wheat which is to be used as seeds, even using low power levels, unless some provisions are made to ensure uniform heating $[124,146-$ 148]. They have concluded that bread making quality of wheat and maize get adversely affected by exposure to microwave radiation. Though microwave heating helped in reducing the power consumption in wheat milling process, the textural characteristics of the final products are made from the microwave-treated flour were found not to be acceptable. The viscosity of the flour decreased with increased exposure time because of the alteration in structure of starch and protein when exposed to microwave energy. Campana et al. [121] had also stated that the protein content was not affected but the functionality of gluten altered gradually with increasing time of exposure. The change in the functionality of gluten is because of the absence of elasticity and stretchability of the dough $[121,147]$.

Several researchers concluded that germination capacity was affected by exposure to microwave energy. The seed viability and germination of chickpea, pigeon pea, and green gram were also reported to be affected by microwave exposure time and power level [106]. Vadivambal et al. [149] found that microwave energy at $2450 \mathrm{MHz}$ with similar heating mechanism to RF treatments might control storage insects in barley and rye but resulted in poor germination due to high sample temperatures. The decrease in germination capacity 
was related to the final temperature and the initial moisture content of the grains. Nelson and Stetson [150] studied the dielectric heating treatments of rice weevils in wheat at 39 and $2450 \mathrm{MHz}$ and showed that the lower frequency was much more effective in killing the insects. Wang et al. [86] had concluded that differential heating of insects in walnuts does occur at $27 \mathrm{MHz}$ but not at $915 \mathrm{MHz}$ based on the experiments carried out on dried nuts and fruits by exposure to microwave and radio frequencies range.

Bhaskara Reddy et al. [122] studied the effect of microwave treatment on quality of wheat seeds infected with Fusarium graminearum (Schwabe). Their results showed that though mortality of insect increased with the microwave power level, but the seed viability and seedling vigor decreased accordingly. It has been concluded that microwave drying of wheat would not be suitable where the final products made out of flour required soft textural characteristics. Another issue with the microwave heating is the large number of factors that affect the microwave heat transfer behavior such as the thickness, the geometry, and the dielectric properties of the food. The heat capacity and the dielectric properties (dielectric constant, loss factor) change with the moisture content and temperature which complicates the microwave heating process. Cost estimates for microwave and radio frequency insect control are estimated to be around three to five times more expensive than chemical control.

\section{Conclusion}

Insects cause considerable damage to food grains with weight and nutritional losses reducing yields and market values. Postharvest phytosanitary treatments are often required to completely control insect pests before the products are moved through marketing channels to areas where the pests do not occur. Several methods have been suggested to control insect pests in agricultural commodities, including chemical fumigation, thermal treatment, ionizing radiation, cold storage, controlled atmospheres, dielectric heating, and combination treatments. Current technologies involve the use of toxic chemicals which is neither consumer friendly nor environmentally friendly and conventional thermal methods are either undesirable or cause loss of volatile components, browning, and texture change. To date, irradiation is not accepted by the organic industry. Based on the results of the microwave disinfestation studies already conducted, it is considered as safe and competitive alternative method to other quarantine methods and can avoid problems of food safety and environmental pollution. The study conducted on different food products infested with major insects says that complete mortality, that is, $100 \%$, could be achieved using microwave energy. Although microwaves have potential for disinfesting the food products, they have not been used widely due to their adverse effects on various quality parameters. Nonuniformity of heating is one of the important factors that cause quality deterioration of food product. Though several practical means can be used to minimize nonuniform heating such as adding forced hot air to the product surface or sample movement/rotation or mixing during treatment, and so forth. Also if the microwave disinfestation is made economical, it may serve as a safe and effective alternate method of insect control. The most important factor in the development of an acceptable insect control method using microwave energy is to identify a balance between minimized thermal impact on the product quality and complete killing of the insect population. To achieve a balance between complete eradication of the insects and to maintain the product quality, further research needs to be done on large scale tests, with infested product to confirm the treatment efficacy and product quality after extended storage before this technology would provide an acceptable process for disinfestation.

\section{Acknowledgment}

The authors acknowledge the Department of Science and Technology (DST), India, for providing financial support for this study.

\section{References}

[1] S. Lal and B. P. Srivastava, "Insect pests of stored wheat of Madhya Pradesh (India)," Journal of Entomological Research, vol. 9, pp. 141-148, 1985.

[2] A. K. Sinha and K. K. Sinha, "Insect pests, Aspergillus flavus and aflatoxin contamination in stored wheat: a survey at North Bihar (India)," Journal of Stored Products Research, vol. 26, no. 4, pp. 223-226, 1990.

[3] B. Subramanyam and D. W. Hagstrum, Alternatives to Pesticides in STored-Product IPM, Kluwer Academic Publishers, Norwell, Mass, USA, 2000.

[4] R. I. Sánchez-MariñEz, M. O. Cortez-Rocha, F. Ortega-Dorame, M. Morales-Valdes, and M. I. Silveira, "End-use quality of flour from Rhyzopertha dominica infested wheat," Cereal Chemistry, vol. 74, no. 4, pp. 481-483, 1997.

[5] F. S. Nasab, A. A. Pourmirza, and A. H. Zade, "The effect of microwave radiation with cold storage on the mortality of Indian meal moth (Plodia Interpunctella Hub.) Eggs," Pakistan Journal of Entomology, vol. 31, no. 2, pp. 111-115, 2009.

[6] J. P. Edwards, J. E. Short, and L. Abraham, "Large-scale evaluation of the insect juvenile hormone analogue fenoxycarb as a long-term protectant of stored wheat," Journal of Stored Products Research, vol. 27, no. 1, pp. 31-39, 1991.

[7] Y. Rajashekar, N. Bakthavatsalam, and T. Shivanandappa, "Review article on botanicals as grain protectants," vol. 2012, Article ID 646740, 13 pages, 2012.

[8] S. Rajendran and V. Sriranjini, "Plant products as fumigants for stored-product insect control," Journal of Stored Products Research, vol. 44, no. 2, pp. 126-135, 2008.

[9] FDA: Food Drug Administration, Wheat Flour-Adulteration With Insect Fragments and Rodent Hairs (CPG, 7104. 06). Compliance Policy Guides Manual, chapter 5, Foods, color and cosmetics, sub chapter 578-processed grain, 1997.

[10] FGIS: Federal Grain Inspection Service, Official United States standards for grain subpart $\mathrm{m}$. United States standards for wheat, 1999.

[11] D. B. Pinniger, M. R. Stubbs, and J. Chambers, "The evaluation of some food attractants for the detection of Oryzaephilus surinamensis (L.) and other storage pests," in Proceedings of 
the 3rd International Working Conference on Stored Product Entomology, pp. 640-650, Kansas, USA, October 1984.

[12] R. Vadivambal, D. S. Jayas, and N. D. White, "Disinfestation of life stages of Tribolium castaneum in wheat using microwave energy," in Proceedings of the CSBE/SCGAB, 2006 Annual Conference Edmonton Alberta, 2006, Paper No. 06-120S.

[13] E. Mitcham, "Quarantine issues in 2000," Acta Horticulture, vol. 553, pp. 451-455, 2001.

[14] J. Gannage, "Pesticides and human health," 2000, http://www .herbs2000.com/articles/pesticides.htm.

[15] R. N. Sinha and F. L. Watters, Insect Pests of Flour Mills, Grain Elevators, and Feed Mills and Their Control, Agriculture Canada, Winnipeg, Canada, 1985.

[16] E. J. Bond, Manual of Fumigation For Insect Control, Food and Agricultural Organization, Rome, Italy, 1984.

[17] J. G. Leesch, G. F. Knapp, and B. E. Mackey, "Methyl bromide adsorption on activated carbon to control emissions from commodity fumigations," Journal of Stored Products Research, vol. 36, no. 1, pp. 65-74, 2000.

[18] UNEP (United Nations Environment Programme), Report of the 9th Meeting of the Parties To the Montreal ProTocol on Substances That Deplete the Ozone Layer, UNEP/OzL.Pro. 9/12, Montreal, Canada, 1997.

[19] S. Rajendran and N. Muralidharan, "Performance of phosphine in fumigation of bagged paddy rice in indoor and outdoor stores," Journal of Stored Products Research, vol. 37, no. 4, pp. 351-358, 2001.

[20] C. H. Bell and S. M. Wilson, "Phosphine tolerance and resistance in Trogoderma granarium Everts (Coleoptera: Dermestidae)," Journal of Stored Products Research, vol. 31, no. 3, pp. 199205, 1995.

[21] B. H. Subramanyam and D. Hagstrum, "Resistance measurement and management," in Integrated Management of Insects in Stored Products, B. Subramanyam and D. Hagstrum, Eds., pp. 331-398, Marcel Dekker, New York, NY, USA, 1995.

[22] P. Collins, G. Daglish, H. Pavic, T. Lambkin, R. Kopittke, and B. Bridgeman, "Combating strong resistance to phosphine in stored grain pests in Australia," in Proceedings of the 2nd Australian Postharvest Technical Conference, E. J. Wright, $\mathrm{H}$. J. Banks, and E. Highley, Eds., pp. 109-112, Adelaide, South Australia, 2000.

[23] S. J. Langlinais, "Economics of microwave treated rice for controlling weevils," ASAE Paper 893544, ASABE, St. Joseph, Mich, USA, 1989.

[24] E. Shadia and S. E. Abd El-Aziz, "Control strategies of stored product pests," Journal of Entomology, vol. 8, no. 2, pp. 101-122, 2011.

[25] P. G. Fields and W. E. Muir, "Physical control" in Integrated Management of Insects in Stored Products, Marcel Dekker, New York, NY, USA, 1996.

[26] J. Banks and J. B. Fields, "Physical methods for insect control in stored-grain ecosystems," in Stored-Grain Ecosystem, D. S. Jayas, N. D. G. White, and W. E. Muir, Eds., pp. 353-410, Marcel Dekker, New York, NY, USA, 1995.

[27] M. Hasan and A. R. Khan, "Control of stored-product pests by irradiation," Integrated Pest Management Reviews, vol. 3, no. 1, pp. 15-29, 1998.

[28] S. Wang and J. Tang, "Radio frequency and microwave alternative treatments for insect control in nuts: A review," International Agricultural Engineering Journal, vol. 10, no. 3-4, pp. 105120, 2001.
[29] G. Saour and H. Makee, "Susceptibility of potato tuber moth (Lepidoptera: Gelechiidae) to postharvest gamma irradiation," Journal of Economic Entomology, vol. 97, no. 2, pp. 711-714, 2004.

[30] N. W. Heather, G. Hallman, and N. Heather, Pest Management and Phytosanitary Trade Barriers, CABi Publishing, Cambridge, Mass, USA, 2008.

[31] M. Gao, J. Tang, Y. Wang, J. Powers, and S. Wang, "Almond quality as influenced by radio frequency heat treatments for disinfestation," Postharvest Biology and Technology, vol. 58, no. 3, pp. 225-231, 2010.

[32] S. O. Nelson, P. G. Hartley, and K. C. Lawrence, "RF and microwave dielectric properties of stored-grain insects and their implications for potential insect control," Transactions of the American Society of Agricultural Engineers, vol. 41, no. 3, pp. 685-692, 1998.

[33] R. Vadivambal, Disinfestation of Stored Grain Insects Using Microwave Energy [Ph.D. thesis], University of Manitoba, Winnipeg, Canada, 2009.

[34] M. S. Venkatesh and G. S. V. Raghavan, "An overview of microwave processing and dielectric properties of agri-food materials," Biosystems Engineering, vol. 88, no. 1, pp. 1-18, 2004.

[35] M. P. Fakude, "Eradication of storage insect pests in maize using microwave energy and the effects of the latter on grain quality," 2007, http://upetd.up.ac.za/thesis/available/etd-01292009131525/unrestricted/dissertation.pdf.

[36] P. C. Annis and R. Morton, "The acute mortality effects of carbon dioxide on various life stages of Sitophilus oryzae," Journal of Stored Products Research, vol. 33, no. 2, pp. 115-124, 1997.

[37] N. Gunasekaran and S. Rajendran, "Toxicity of carbon dioxide to drugstore beetle Stegobium paniceum and cigarette beetle Lasioderma serricorne," Journal of Stored Products Research, vol. 41, no. 3, pp. 283-294, 2005.

[38] D. E. Evans, "Some biological and physical constraints to the use of heat and cold for disinfesting and preserving stored products," in Proceedings of the 4th International Working Conference of Stored Product Protection, E. Donahaye and S. Navarro, Eds., pp. 149-164, Tel-Aviv, Israel, 1986.

[39] J. L. Sharp, J. J. Gaffney, J. I. Moss, and W. P. Gould, "Hot-air treatment device for quarantine research," Journal of Economics Entomology, vol. 84, pp. 520-527, 1991.

[40] P. G. Fields, "The control of stored-product insects and mites with extreme temperatures," Journal of Stored Products Research, vol. 28, no. 2, pp. 89-118, 1992.

[41] V. Y. Yokoyama, G. T. Miller, and R. V. Dowell, "Response of codling Moth (Lepidoptera: Tortricidae) to high temperature, a potential quarantine treatment for exported commodities," Journal of Economics Entomology, vol. 84, pp. 528-531, 1991.

[42] L. G. Neven, "Combined heat treatments and cold storage effects on mortality of fifth-instar codling moth (Lepidoptera: Tortricidae)," Journal of Economic Entomology, vol. 87, no. 5, pp. 1262-1265, 1994.

[43] L. G. Neven and L. M. Rehfield, "Comparison of Pre-Storage Heat Treatments on Fifth-Instar Codling Moth (Lepidoptera: Tortricidae) Mortality," Journal of Economic Entomology, vol. 88, pp. 1371-1375, 1995.

[44] L. J. Mason and C. A. Strait, "Stored product integrated pest management with extreme temperatures," in Temperature Sensitivity in Insects and Application in Integrated Pest Management, G. J. Hallman and D. L. Denlinger, Eds., pp. 141-177, Westview Press, Boulder, Colo, USA, 1998. 
[45] A. K. Dowdy, "Heat sterilization as an alternative to methyl bromide fumigation in cereal processing plants," in Proceedings of 7th International Working Conference for Stored Product Protection, Z. Jin, Q. Liang, Y. Liang, X. Tan, and L. Guan, Eds., pp. 1089-1095, Beijing, China, 1999.

[46] C. S. Burks, J. A. Johnson, D. E. Maier, and J. W. Heaps, "Temperature.", in Alternatives to Pesticides in stored Product IPM, B. Subramanyam and D. W. Hagstrum, Eds., pp. 73-104, Kluwer Academic Publishers, Boston, Mass, USA, 2000.

[47] J. Tang, J. N. Ikediala, S. Wang, J. D. Hansen, and R. P. Cavalieri, "High-temperature-short-time thermal quarantine methods," Postharvest Biology and Technology, vol. 21, no. 1, pp. 129-145, 2000.

[48] S. Wang, J. N. Ikediala, J. Tang et al., "Radio frequency treatments to control codling moth in in-shell walnuts," Postharvest Biology and Technology, vol. 22, no. 1, pp. 29-38, 2001.

[49] S. Wang, J. Tang, and R. P. Cavalieri, "Modeling fruit internal heating rates for hot air and hot water treatments," Postharvest Biology and Technology, vol. 22, no. 3, pp. 257-270, 2001.

[50] S. Lurie, T. Jemric, A. Weksler, R. Akiva, and Y. Gazit, "Heat treatment of 'Oroblanco' citrus fruit to control insect infestation," Postharvest Biology and Technology, vol. 34, no. 3, pp. 321329, 2004.

[51] M. Schirra, M. Mulas, A. Fadda, I. Mignani, and S. Lurie, "Chemical and quality traits of "Olinda" and "Campbell" oranges after heat treatment at 44 or $46 \circ \mathrm{C}$ for fruit fly disinfestation," LWT-Food Science and Technology, vol. 38, no. 5, pp. 519-527, 2005.

[52] O. Dosland, B. Subramanyam, K. Sheppard, and R. Mahroof, "Temperature modification for insect control," in Insect Management For Food Storage and Processing, J. Heaps, Ed., pp. 89103, American Association of Cereal Chemists, St. Paul, Minn, USA, 2005.

[53] S. J. Beckett, P. G. Fields, and B. Subramanyam, "Disinfestation of stored products and associated structures using heat," in Heat Treatments For Postharvest Pest Control: Theory and Practice, J. Tang, E. Mitcham, S. Wang, and S. Lurie, Eds., CAB International, Wallingford, UK, 2006.

[54] O. Dosland, B. Subramanyam, K. Sheppard, and R. Mahroof, "Temperature modification for insect control," in Insect Management For Food Storage and Processing, J. Heaps, Ed., pp. 89-103, American Association for Clinical Chemistry, St. Paul, Minn, USA, 2nd edition, 2006.

[55] E. J. Mitcham, S. Zhou, and V. Bikoba, "Controlled atmospheres for quarantine control of three pests of table grape," Journal of Economic Entomology, vol. 90, no. 5, pp. 1360-1370, 1997.

[56] R. W. Howe, "A summary of estimates of optimal and minimal conditions for population increase of some stored products insects," Journal of Stored Products Research, vol. 1, no. 2, pp. 177-184, 1965.

[57] J. Hansen, "Heating curve models of quarantine treatments against insect pests," Journal of Economics Entomology, vol. 85, pp. 1846-1854, 1992.

[58] S. Lurie, "Postharvest heat treatments," Postharvest Biology and Technology, vol. 14, no. 3, pp. 257-269, 1998.

[59] S. Wang, X. Yin, J. Tang, and J. D. Hansen, "Thermal resistance of different life stages of codling moth (Lepidoptera: Tortricidae)," Journal of Stored Products Research, vol. 40, no. 5, pp. 565$574,2004$.

[60] G. J. Hallman, J. J. Gaffney, and J. L. Sharp, "Vapor heat treatment for grapefruit infested with Caribbean fruit fly (Diptera:
Tephritidae)," Journal of Economic Entomology, vol. 83, no. 4, pp. 1475-1478, 1990.

[61] D. Ortega-Zaleta and E. M. Yahia, “Tolerance and quality of mango fruit exposed to controlled atmospheres at high temperatures," Postharvest Biology and Technology, vol. 20, no. 2, pp. 195-201, 2000.

[62] K. C. Shellie, R. L. Mangan, and S. J. Ingle, “Tolerance of grapefruit and mexican fruit fly larvae to heated controlled atmospheres," Postharvest Biology and Technology, vol. 10, no. 2, pp. 179-186, 1997.

[63] E. L. Kerbel, G. Mitchell, and G. Mayer, "Effect of postharvest heat treatment for insect control on the quality and market life of avocados," Horticultural Science, vol. 22, pp. 92-94, 1987.

[64] K. J. Smith and M. Lay-Yee, "Response of "Royal Gala" apples to hot water treatment for insect control," Postharvest Biology and Technology, vol. 19, no. 2, pp. 111-122, 2000.

[65] D. M. Obenland, M. L. Arpaia, R. K. Austin, and B. E. MacKey, "High-temperature forced-air treatment alters the quantity of flavor-related, volatile constituents present in navel and valencia oranges," Journal of Agricultural and Food Chemistry, vol. 47, no. 12 , pp. $5184-5188,1999$.

[66] D. B. Thomas and K. C. Shellie, "Heating rate and induced thermotolerance in Mexican fruit fly (diptera: tephritidae) larvae, a quarantine pest of citrus and mangoes," Journal of Economic Entomology, vol. 93, no. 4, pp. 1373-1379, 2000.

[67] S. J. Beckett and R. Morton, "Mortality of Rhyzopertha dominica (F.) (Coleoptera: Bostrychidae) at grain temperatures ranging from $50 \circ \mathrm{C}$ to $60 \circ \mathrm{C}$ obtained at different rates of heating in a spouted bed," Journal of Stored Products Research, vol. 39, no. 3, pp. 313-332, 2003.

[68] S. Wang and J. Tang, "Heating uniformity and differential heating of insects in almonds in radio frequency systems," Paper 076019, American Society of Agricultural and Biological Engineers, St. Joseph, Mich, USA, 2007.

[69] X. Yin, S. Wang, J. Tang, J. D. Hansen, and S. Lurie, "Thermal conditioning of fifth-instar Cydia pomonella (Lepidoptera: Tortricidae) affects HSP70 accumulation and insect mortality," Physiological Entomology, vol. 31, no. 3, pp. 241-247, 2006.

[70] D. E. Evans, G. R. Thorpe, and T. Dermott, "The disinfestation of wheat in a continuous-flow fluidized bed," Journal of Stored Products Research, vol. 19, no. 3, pp. 125-137, 1983.

[71] Y. C. Fu, "Fundamentals and industrial applications of microwave and radio frequency in food processing," in Food Processing: Principles and Applications, J. S. Smith and Y. H. Hui, Eds., Blackwell, Iowa City, IA, Iowa, USA, 2004.

[72] M. A. Stuchly, "Health effects of exposure to electromagnetic fields," IEEE Aerospace Applications Conf Proceeding, vol. 1, pp. 351-368, 1995.

[73] S. O. Nelson and J. A. Payne, "RF dielectric heating for pecan weevil control," Transactions of the American Society of Agricultural Engineers, vol. 31, pp. 456-458, 1982.

[74] D. Andreuccetti, M. Bini, A. Ignesti, A. Gambetta, and R. Olmi, "Microwave destruction of woodworms," Journal of Microwave Power and Electromagnetic Energy, vol. 29, no. 3, pp. 153-160, 1994.

[75] S. O. Nelson, "Review and assessment of radio-frequency and microwave energy for stored-grain insect control," Transactions of the American Society of Agricultural Engineers, vol. 39, no. 4, pp. 1475-1484, 1996.

[76] S. Wang, J. N. Ikediala, J. Tang, and J. D. Hansen, “Thermal death kinetics and heating rate effects for fifth-instar Cydia 
pomonella (L.) (Lepidoptera: Tortricidae)," Journal of Stored Products Research, vol. 38, no. 5, pp. 441-453, 2002.

[77] S. Wang, J. Tang, J. A. Johnson, and J. D. Hansen, “Thermaldeath kinetics of fifth-instar Amyelois transitella (Walker) (Lepidoptera: Pyralidae)," Journal of Stored Products Research, vol. 38, no. 5, pp. 427-440, 2002.

[78] S. Wang, J. Tang, J. A. Johnson et al., "Process protocols based on radio frequency energy to control field and storage pests in inshell walnuts," Postharvest Biology and Technology, vol. 26, no. 3, pp. 265-273, 2002.

[79] E. J. Mitcham, R. H. Veltman, X. Feng et al., "Application of radio frequency treatments to control insects in in-shell walnuts," Postharvest Biology and Technology, vol. 33, no. 1, pp. 93-100, 2004.

[80] F. Marra, L. Zhang, and J. G. Lyng, "Radio frequency treatment of foods: review of recent advances," Journal of Food Engineering, vol. 91, no. 4, pp. 497-508, 2009.

[81] S. Wang, G. Tiwari, S. Jiao, J. A. Johnson, and J. Tang, "Developing postharvest disinfestations treatments for legumes using radio frequency energy," Biosystems Engineering, vol. 105, no. 3, pp. 341-349, 2010.

[82] S. Jiao, J. A. Johnson, J. K. Fellman et al., "Evaluating the storage environment in hypobaric chambers used for disinfesting fresh fruits," Biosystems Engineering, vol. 111, no. 3, pp. 271-279, 2012.

[83] S. Wang, M. Monzon, J. A. Johnson, E. J. Mitcham, and J. Tang, "Industrial-scale radio frequency treatments for insect control in walnuts. I: Heating uniformity and energy efficiency," Postharvest Biology and Technology, vol. 45, no. 2, pp. 240-246, 2007.

[84] S. Wang, M. Monzon, J. A. Johnson, E. J. Mitcham, and J. Tang, "Industrial-scale radio frequency treatments for insect control in walnuts. II: Insect mortality and product quality," Postharvest Biology and Technology, vol. 45, no. 2, pp. 247-253, 2007.

[85] M. C. Lagunas-Solar, Z. Pan, N. X. Zeng, T. D. Truong, R. Khir, and K. S. P. Amaratunga, "Application of radiofrequency power for non-chemical disinfestation of rough rice with full retention of quality attributes," Applied Engineering in Agriculture, vol. 23, no. 5, pp. 647-654, 2007.

[86] S. Wang, J. Tang, R. P. Cavalieri, and D. C. Davis, "Differential heating of insects in dried nuts and fruits associated with radio frequency and microwave treatments," Transactions of the American Society of Agricultural Engineers, vol. 46, no. 4, pp. 1175-1182, 2003.

[87] S. Wang, J. Tang, J. A. Johnson et al., "Dielectric properties of fruits and insect pests as related to radio frequency and microwave treatments," Biosystems Engineering, vol. 85, no. 2, pp. 201-212, 2003.

[88] S. L. Halverson, R. Plarre, T. S. Bigelow, and K. Lieber, "Recent advance in the use of EHF energy for the control of insect in stored products," in Proceedings of the ASAE Annual International Meeting, Orlando, Fla, USA, 1998, Paper No. 986052.

[89] J. N. Ikediala, J. Tang, L. G. Neven, and S. R. Drake, "Quarantine treatment of cherries using $915 \mathrm{MHz}$ microwaves: temperature mapping, codling moth mortality and fruit quality," Postharvest Biology and Technology, vol. 16, no. 2, pp. 127-1, 1999.

[90] O. A. Karabulut and N. Baykal, "Evaluation of the use of microwave power for the control of postharvest diseases of peaches," Postharvest Biology and Technology, vol. 26, no. 2, pp. 237-240, 2002.

[91] F. L. Watters, "Microwave radiation for control of Tribolium confusum in wheat and flour," Journal of Stored Products Research, vol. 12, no. 1, pp. 19-25, 1976.
[92] M. A. K. Hamid, C. S. Kashyap, and R. V. Cauwenberghe, "Control of grain insects by microwave power," Journal of Microwave Power, vol. 3, no. 3, pp. 126-135, 1968.

[93] S. L. Halverson, T. W. Phillips, T. S. Bigelow, G. N. Mbata, and M. E. Payton, "The control of various species of stored-product insects with EHF energy," in Proceeding of the Annual International Research Conference on Methyl Bromide Alternatives and Emissions Reductions, pp. 54-1-54-4, 1999.

[94] R. V. Decareau, Microwaves in the Food Processing Industry, Academic Press, Natick, Mass, USA, 1985.

[95] P. P. Sutar and S. Prasad, "Microwave drying technology-recent developments and $\mathrm{R} \& \mathrm{D}$ needs in India," in proceedings of the 42nd ISAE Annual Convention, pp. 1-3, Kolkata, India, February 2008.

[96] H. Linn and M. Moller, "Microwave heating," in Proceedings of the Thermprocess Symposium, pp. 16-21, Dusseldorf, Germany, June 2003.

[97] S. O. Nelson and S. Trabelsi, "Factors influencing the dielectric properties of agricultural and food products," Journal of Microwave Power and Electromagnetic Energy, vol. 46, no. 2, pp. 93-107, 2012.

[98] E. W. Tilton and H. H. Vardell, "Combination of microwaves and partial vacuum for control of four stored-product insects in stored grain," Georgia Entomological Society, vol. 17, pp. 96$106,1982$.

[99] E. W. Tilton and J. H. Brower, "Ionizing radiation for insect control in grain and grain products," Cereal Foods World, vol. 32, no. 4, pp. 330-335, 1987.

[100] N. Shayesteh and N. N. Barthakur, "Mortality and behaviour of two stored-product insect species during microwave irradiation," Journal of Stored Products Research, vol. 32, no. 3, pp. 239246, 1996.

[101] S. S. Bedi and M. Singh, "Microwaves for control of stored grain insects," National Academy of Science Letter, vol. 15, no. 6, pp. 195-197, 1992.

[102] D. Sanchez-Hernandez, J. V. Balbastre, and J. M. Osca, "Microwave energy as a viable alternative to methyl bromide and other pesticides for rice disinfection of industrial processes," in Proceedings of International Conference on Alternatives to Methyl Bromide, pp. 159-162, Sevilla, Spain, March 2002.

[103] W. R. Halverson, T. S. Bigelow, and S. L. Halverson, "Design of High-Power Microwave Applicator for the Control of Insects in Stored Products," in Proceedings of the Annual International Meeting, pp. 27-30, American Society for Agricultural Engineers, Las Vegas, Nev., USA, July 2003, Paper No. 036156.

[104] R. Vadivambal, D. S. Jayas, and N. D. G. White, "Wheat disinfestation using microwave energy," Journal of Stored Products Research, vol. 43, no. 4, pp. 508-514, 2007.

[105] R. Vadivambal, O. F. Deji, D. S. Jayas, and N. D. G. White, "Disinfestation of stored corn using microwave energy," Agriculture and Biology Journal of North America, vol. 1, no. 1, pp. 18-26, 2010.

[106] R. Singh, K. K. Singh, and N. Kotwaliwale, "Study on disinfestation of pulses using microwave technique," Journal of Food Science and Technology, vol. 49, no. 4, pp. 505-509, 2012.

[107] R. Pande, H. N. Mishra, and M. N. Singh, "Microwave drying for safe storage and improved nutritional quality of green gram seed (Vigna radiata)," Journal of Agricultural and Food Chemistry, vol. 60, pp. 3809-3816, 2012.

[108] S. L. Halverson, W. E. Burkholder, T. S. Bigelow, E. V. Norsheim, and M. E. Misenheimer, "High-power microwave radiation 
as an alternative insect control method for stored products," Journal of Economic Entomology, vol. 89, no. 6, pp. 1638-1648, 1996.

[109] H. H. Webber, R. P. Wangner, and A. G. Pearson, "High frequency electric fields as lethal agents for insects," Journal of Economics Entomology, vol. 39, pp. 481-498, 1946.

[110] S. O. Nelson, "Dielectric properties of agricultural products: measurements and applications," IEEE Transactions on Electrical Insulation, vol. 26, no. 5, pp. 845-869, 1991.

[111] S. O. Nelson, "Radio-frequency and microwave dielectric properties of insects," Journal of Microwave Power and Electromagnetic Energy, vol. 36, no. 1, pp. 47-56, 2001.

[112] S. O. Nelson and W. K. Whitney, "Radiofrequency electric fields for stored grain insect control," Transactions of the American Society of Agricultural Engineers, vol. 3, no. 2, pp. 133-137, 1960.

[113] S. O. Nelson, L. E. Stetson, and J. J. Rhine, "Factors Influencing Effectiveness of Radiofrequency Electric Fields for StoredGrain Insect Control," Transactions of the American Society of Agricultural Engineers, vol. 9, pp. 809-815, 1966.

[114] S. O. Nelson, "Electromagnetic Energy," in Pest Control, Biological, Physical and Selected Chemical Methods, W. W. Kilgore and R. L. Doutt, Eds., pp. 89-145, Academic Press, New York, NY, USA, 1967.

[115] B. Alfaifi, J. Tang, B. Rasco, S. Sablani, and Y. Jiao, "Radio frequency disinfestation treatments for dried fruit: dielectric properties," LWT-Food Science and Technology, vol. 50, no. 2, pp. 746-754, 2013.

[116] J. N. Ikediala, J. Tang, and T. Wig, "A heating block system for studying thermal death kinetics of insect pests," Transactions of the American Society of Agricultural Engineers, vol. 43, no. 2, pp. 351-358, 2000.

[117] V. M. Rashkovan, N. A. Khizhnyak, A. V. Basteev, L. A. Bazyma, L. Niño de Rivera, and I. A. Ponomaryova, "Interaction of electromagnetic waves with granular agricultural product and insects," Journal of Microwave Power and Electromagnetic Energy, vol. 38, no. 4, pp. 1-12, 2003.

[118] J. Tang, "Dielectric Properties of foods," in Microwave Processing of Foods, H. Schubert and M. Regier, Eds., CRC Press, Cambridge UK, 2005.

[119] A. C. Metaxas and R. J. Meredith, Industrial Microwave Heating, Peter Peregrinus, 1983.

[120] G. J. Hallman and J. L. Sharp, "Radio Frequency Heat Treatments," in Quarantine Treatments For Pests of Food Plants, J. L. Sharp and G. J. Hallman, Eds., pp. 165-170, Westview Press, San Francisco, Calif, USA, 1994.

[121] L. E. Campana, M. E. Sempe, and R. R. Filgueira, "Physical, chemical and baking properties of wheat dried with microwave energy," Cereal Chemistry, vol. 70, no. 6, pp. 760-762, 1993.

[122] M. V. Bhaskara Reddy, G. S. V. Raghavan, A. C. Kushalappa, and T. C. Paulitz, "Effect of microwave treatment on quality of wheat seeds infected with Fusarium graminearum," Journal of Agricultural Engineering Research, vol. 71, no. 2, pp. 113-117, 1998.

[123] J. Kaasova, B. Hubackova, P. Kadlec, J. Prihoda, and Z. O. Bubnik, "Chemical and biochemical changes during microwave treatment of wheat," Czech Journal of Food Science, vol. 20, pp. 74-78, 2002.

[124] M. A. K. Hamid and R. J. Boulanger, "A new method for the control of moisture and insect infestations of grain by microwave power," Journal of Microwave Power, vol. 4, no. 1, pp. 11-18, 1969.
[125] D. P. Locatelli and S. Traversa, "Microwaves in the Control of Rice Infestants," Italian Journal of Food Science, vol. 1, no. 2, p. 62, 1989.

[126] J. L. Sharp and R. G. McGuire, "Control of Caribbean fruit fly (Diptera: Tephritidae) in navel orange by forced hot air," Journal of Economic Entomology, vol. 89, no. 5, pp. 1181-1185, 1996.

[127] K. C. Shellie and R. L. Mangan, "Disinfestation: effect of nonchemical treatments on market quality of fruit," in Postharvest Handling of Tropical Fruits, B. R. Champ, Ed., ACIAR Proceedings, pp. 304-310, 1994.

[128] J. A. Johnson, K. A. Valero, S. Wang, and J. Tang, "Thermal death kinetics of red flour beetle (Coleoptera: Tenebrionidae)," Journal of Economic Entomology, vol. 97, no. 6, pp. 1868-1873, 2004.

[129] K. C. Shellie and R. L. Mangan, "Tolerance of red fleshed grapefruit to a constant or stepped temperature, forced-air quarantine heat treatment," Postharvest Biology and Technology, vol. 7, no. 1-2, pp. 151-159, 1996.

[130] D. R. Wilkin and G. Nelson, Control of Insects in Confectionery Walnuts Using Microwaves, vol. 87, British Crop Protection Council Monograph, Berks, UK, 1987.

[131] A. Zouba, O. Khoualdia, A. Antoneo Diaferia, V. Valereo Rosito, H. Bouabidi, and B. Chermiti, "Microwave Treatment for Postharvest Control of the Date Moth Ectomyelois ceratoniae," Tunisian Journal of Plant Protection, vol. 4, no. 2, pp. 173-183, 2012.

[132] S. Ryynanen, H. Tuorila, and L. Hyvonen, "Perceived temperature effects on microwave-heated meals and meal components," Food Service Technology, vol. 1, pp. 141-148, 2001.

[133] D. S. Lee, D. Shin, and K. L. Yam, "Improvement of temperature uniformity in microwave-reheated rice by optimizing heat/cold cycle," Food Service Technology, vol. 2, no. 2, pp. 87-93, 2002.

[134] N. Sakai, C. Wang, S. Toba, and M. Watanabe, "An analysis of temperature distributions in microwave heating of foods with non-uniform dielectric properties," Journal of Chemical Engineering of Japan, vol. 37, no. 7, pp. 858-862, 2004.

[135] A. Manickavasagan, D. S. Jayas, and N. D. G. White, "Nonuniformity of surface temperatures of grain after microwave treatment in an industrial microwave dryer," Drying Technology, vol. 24, no. 12, pp. 1559-1567, 2006.

[136] S. Gunasekaran and H. W. Yang, "Effect of experimental parameters on temperature distribution during continuous and pulsed microwave heating," Journal of Food Engineering, vol. 78, no. 4, pp. 1452-1456, 2007.

[137] S. S. R. Geedipalli, V. Rakesh, and A. K. Datta, "Modeling the heating uniformity contributed by a rotating turntable in microwave ovens," Journal of Food Engineering, vol. 82, no. 3, pp. 359-368, 2007.

[138] A. Manickavasagan, D. S. Jayas, and N. D. G. White, "Germination of wheat grains from uneven microwave heating in an industrial microwave dryer," Canadian Biosystems Engineering, vol. 49, pp. 323-327, 2007.

[139] J. M. Hill and M. J. Jennings, "Formulation of model equations for heating by microwave radiation," Applied Mathematical Modelling, vol. 11, pp. 369-319, 1993.

[140] Z. Songping, Z. Yinglong, and T. R. Marchant, "A DRBEM model for microwave heating problems," Applied Mathematical Modelling, vol. 19, no. 5, pp. 287-297, 1995.

[141] A. Ayvaz and S. Karabörklü, "Effect of cold storage and different diets on Ephestia kuehniella Zeller," Journal of Pest Science, vol. 81, no. 1, pp. 57-62, 2008. 
[142] S. Gasemzadeh, A. Pourmirza, M. Safaralizadeh, and M. Maroufpoor, "Effect of microwave radiation and cold storage on Tribolium castaneum Herbst (Coleoptera: Tenebrionidae) and Sitophilus oryzae L. (Coleoptera: Curculionidae)," Journal of Plant Protection Research, vol. 50, no. 2, pp. 140-145, 2010.

[143] O. Valizadegan, A. A. Pourmirza, and M. H. Safaralizadeh, "The impact of microwaves irradiation and temperature manipulation for control of stored-products insects," African Journal of Biotechnology, vol. 10, no. 61, pp. 13256-13262, 2011.

[144] S. M. El-Naggar and A. A. Mikhaiel, "Disinfestation of stored wheat grain and flour using gamma rays and microwave heating," Journal of Stored Products Research, vol. 47, no. 3, pp. 191-196, 2011.

[145] M. Amjad and M. Akbar Anjum, "Effect of gamma radiation on onion seed viability, germination potential, seedling growth and morphology," Pakistan Journal of Agriculture, vol. 39, pp. 202206, 2002.

[146] N. C. Doty and C. W. Baker, "Microwave conditioning of hard red spring wheat. I. Effects of wide power range on flour and bread quality," Cereal Chemistry, vol. 54, pp. 717-727, 1977.

[147] S. G. Walde, K. Balaswamy, V. Velu, and D. G. Rao, "Microwave drying and grinding characteristics of wheat (Triticum aestivum)," Journal of Food Engineering, vol. 55, no. 3, pp. 271-276, 2002.

[148] V. Velu, A. Nagender, P. G. Prabhakara Rao, and D. G. Rao, "Dry milling characteristics of microwave dried maize grains (Zea mays L.)," Journal of Food Engineering, vol. 74, no. 1, pp. 30-36, 2006.

[149] R. Vadivambal, D. S. Jayas, and N. D. G. White, "Mortality of stored-grain insects exposed to microwave energy," Transactions of the ASABE, vol. 51, no. 2, pp. 641-647, 2008.

[150] S. O. Nelson and L. E. Stetson, "Possibilities for vontrolling insects with microwaves and lower frequency RF energy," IEEE Transactions on Microwave Theory and Techniques, vol. 22, no. 12, pp. 1303-1305, 1974. 

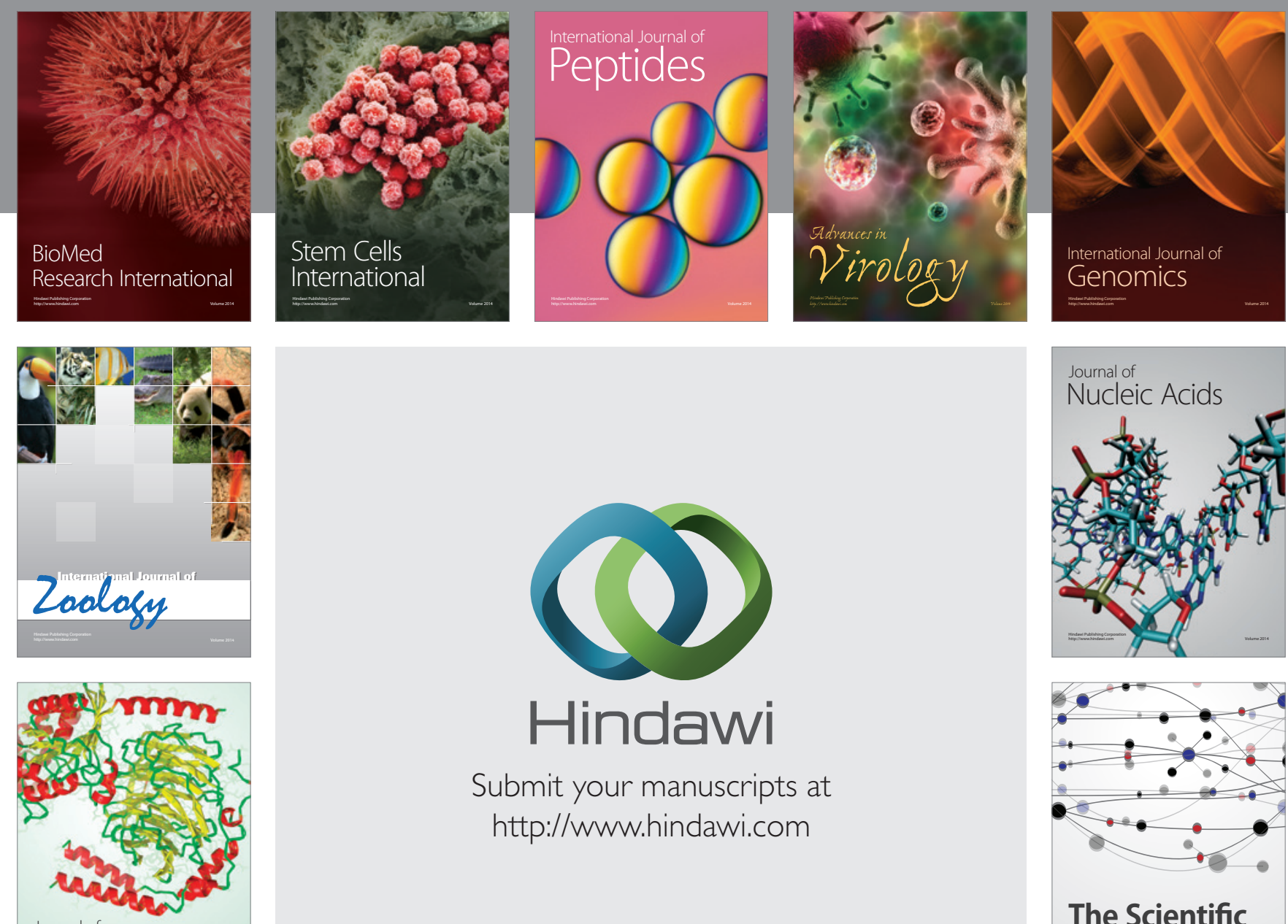

Submit your manuscripts at

http://www.hindawi.com

Journal of
Signal Transduction
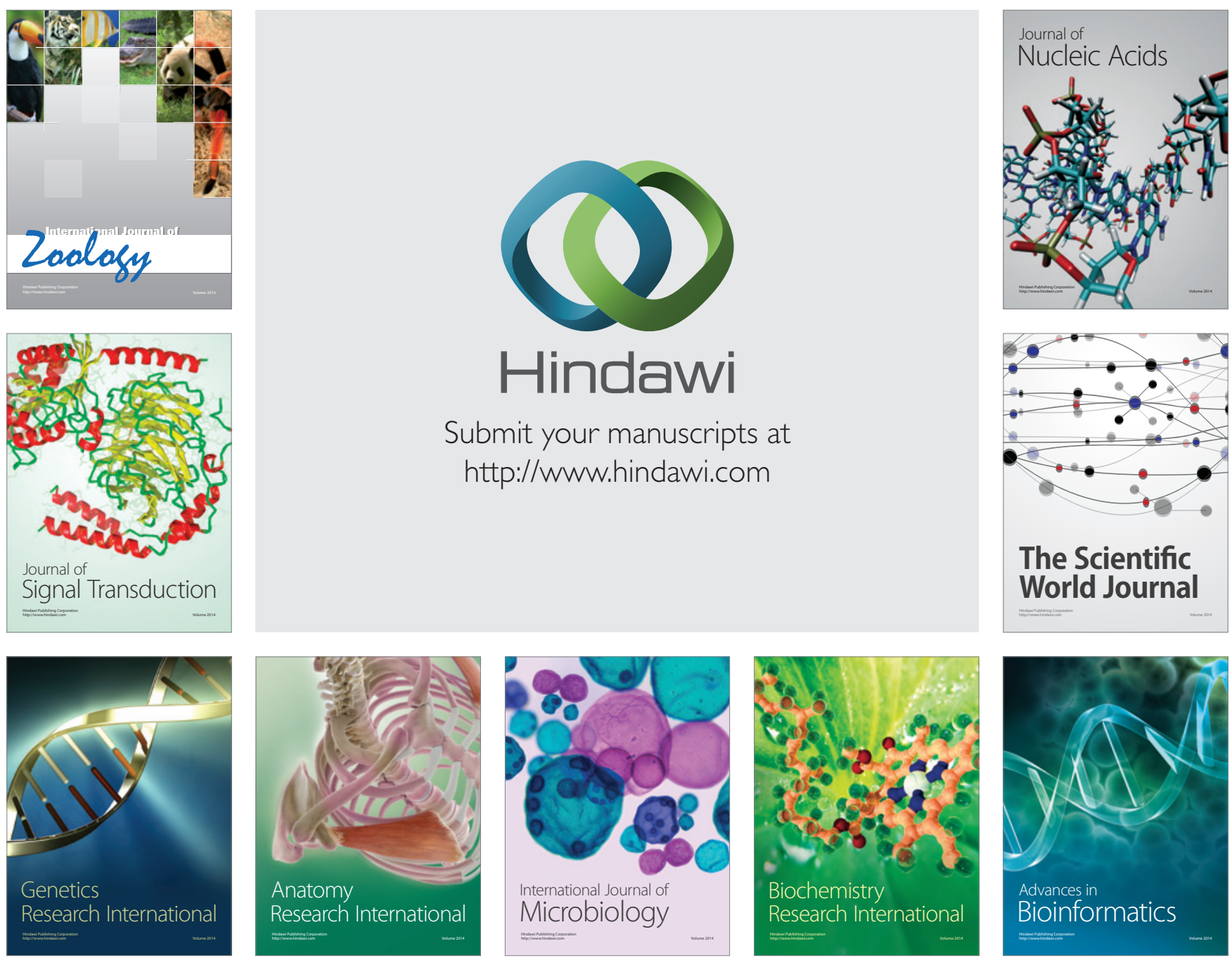

The Scientific World Journal
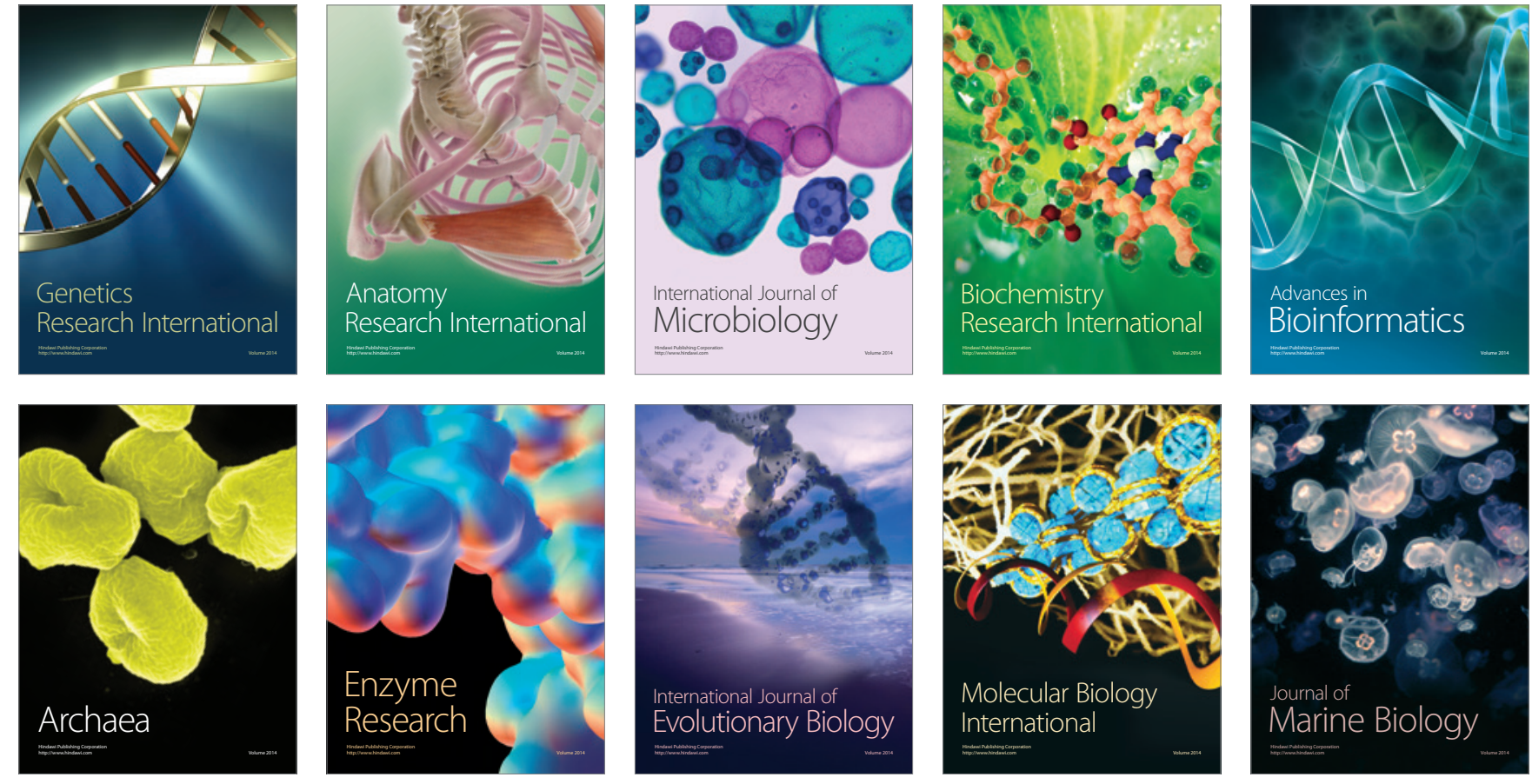